\title{
Culturing Microalgae from Nature: Simple Experiment During Pandemic Covid-19
}

\author{
Alisha Revalia Ghassani Amir ${ }^{1 *}$, Tri Retnaningsih Soeprobowati ${ }^{1,2,3}$, Riche Hariyati ${ }^{1,}$ \\ Jumari $^{1,2}$, Murningsih ${ }^{1}$, Lilih Khotimperwati ${ }^{1,2}$, and Udi Tarwotjo ${ }^{1}$ \\ ${ }^{1}$ Biology Department, Faculty of Science and Mathematics, Universitas Diponegoro, Semarang, \\ Indonesia \\ ${ }^{2}$ Center for Paleolimnology, School of Postgraduate Studies, Universitas Diponegoro, \\ Semarang, Indonesia \\ ${ }^{3}$ School of Postgraduate Studies, Universitas Diponegoro, Semarang, Indonesia
}

Correspondence author: trsoeprobowati@live.undip.ac.id

\begin{abstract}
Microalgae are protists with eukaryotic cell structures which can be found in aquatic ecosystems such as rivers, lakes, reservoirs, ponds, and oceans. The protist culture method can be considered as a technique to allow protists to grow in a certain controlled environment. The objective of this study was to determine the growth of microalgae in the different water sources A modified closed photo-bioreactor (bottle) was used in this research. The number of experiments was 130 , each experiment comparing 5 different natural water resources which are well, pond, pool, paddle, river, tap water, and mineral water and tap water as control, all with 25 replications. Those bottles were put under the sun for 2 weeks. Every day, the colour changes were documented. The result showed that within 2 weeks, no colour changes for mineral and tap waters. On the fourth and fifth days, the watercolour of rivers, ponds, paddle, pools turn the greenish or murky brownish. This indicated the growth of microalgae in the bottle. The different colour indicates the different species or a group of species. This simple experiment able to be developed for practical work during pandemic Covid-19, when students have to study at home, but are still able to get their competence by small project-based learning.
\end{abstract}

Keywords: microalgae, culture, growth, practical work, small project-based learning

\section{Introduction}

Microalgae are protists with eukaryotic cell structures which can be found in waters either marine or freshwater systems such as rivers, lakes, reservoirs, ponds, and oceans. They are

* Alisha Revalia Ghassani Amir : ade.alisha@gmail.com 
primary producers in the aquatic ecosystems that convert water and carbon dioxide to biomass and oxygen in the presence of sunlight [1,2] Microalgae can be cultivated in open (open ponds) or closed photobioreactor (PBR) [3]. The closed systems allow better control of operating parameters leading to higher productivities, but require greater capital investment and more energy to be operated. By using a PBR system, microalgae cultivation can be more controlled such as mass flux, contamination, temperature, $\mathrm{pH}$, gas transfer, and nutrient distribution [4]. The protist culture method can be considered as a technique with the aim to allow protists to grow in a certain controlled environment. Nowadays cultured microalgae are used as direct feed for humans, land-based farm animals, and as feed for cultured aquatic species such as molluscs and the early larval stages of fish and crustaceans [5]. It is also a potential candidate for biofuel production [6]. In this study, we strive to determine the growth of microalgae in the different water sources.

\section{Methods}

This research was conducted in March 2021 using a simple modified closed photobioreactor.

\subsection{Experimental Equipment}

The equipment that was used in this research were 5 used plastic bottles, labels, and 5 different sources of water. The number of experiments was 130, each experiment comparing 5 water resources including mineral water as the control. Five bottles with different water sources were put under the sun for 2 weeks. The water sources used in this experiment were mineral water (130), tap water (84), puddle (89), river (89), pool (91), aquarium (23), groundwater (4), rainwater (29), lake (4), reservoir (8), well (53), rice field (6), spring water (4), and ocean (1).

\subsection{Experimental Procedures}

5 bottles that had been filled with different waters were sealed and placed where they will be exposed to sunlight. The changes in colour of water was observed every day and pictures were taken for 14 days of the experiment. The optimal population growth was analysed based on the colour changes. The darker green colour indicated the higher population and determines on which day it can be harvested.

\section{Results}

\subsection{Observation of Microalgae Growth}

\subsubsection{Tap and Mineral Water}

The result of Mineral and tap (PDAM) water does not show any growth of microalgae within 14 days of observation. Mineral and tap water does not change colour or form sediment because it has been processed in such a way that it is suitable for public consumption.

\subsubsection{River Water}

The change was first seen on the was fourth day where on that day there was a change in colour which was marked by the presence of brown and green dots in spring water and river 
water (Fig 1). River water microalgae tend to stick to the bottom of the bottle, on the wall or float on the surface of the water which is yellow-brown in colour. The river water was taken in Diponegoro University, based on sampling observations, the river has a fairly slow flow where there are rocks on the edge of the river that can be a substrate for living microalgae.
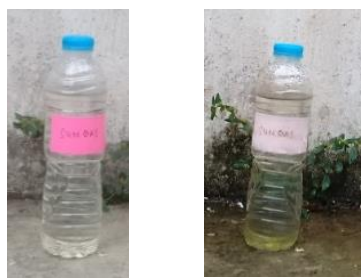

Fig. 1. Microalgae observation for 14 days in river water

\subsubsection{Spring Water}

The peak of microalgae growth was on the 10th day of observation (Fig 2). The microalgae in the spring water became more concentrated and the colonies were clearly visible. The spring was used located in the middle of a densely populated residential area. This spring water is still used by local residents for household activities such as washing. Nutrients in spring water are assumed to come from the remains of dead plants around the spring wall which is located under the road. This of course allows the entry of water from the ditch to the spring when it rains heavily so that the sewer water overflows. spring water microalgae collect or settles at the bottom of the bottle and is dark green in colour.
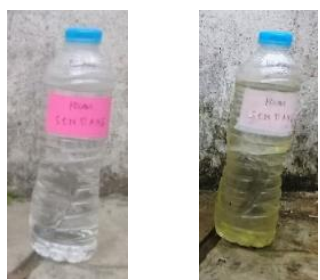

Fig. 2. Microalgae observation for 14 days in spring water

\subsubsection{Puddle Water}

The puddle water changes colour, namely a clear green colour change (Fig 3). The puddle water was colonized on the fifth day, which was marked by a yellowish colour. The colour in the puddle water is getting darker and shows a colour difference. Puddle water tends to be green. The growth of micro-algae in the puddle water increased rapidly and continues to experience a significant change as days go by.
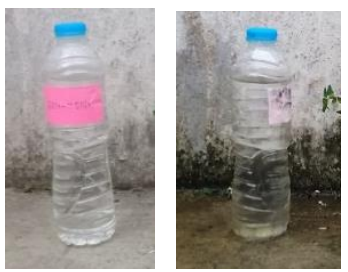
Fig. 3. Microalgae observation for 14 days in puddle water

\subsubsection{Waste Water}

The results obtained after 14 days of observation from waste water turned from clear to yellowish on the $4^{\text {th }}$ day then brown on $11^{\text {th }}$ day (Fig 4). The change in colour indicated microalgae growth.

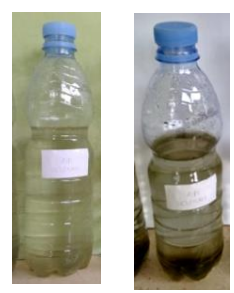

Fig. 4. Microalgae observation for 14 days in waste water

\subsection{6 -Population growth}

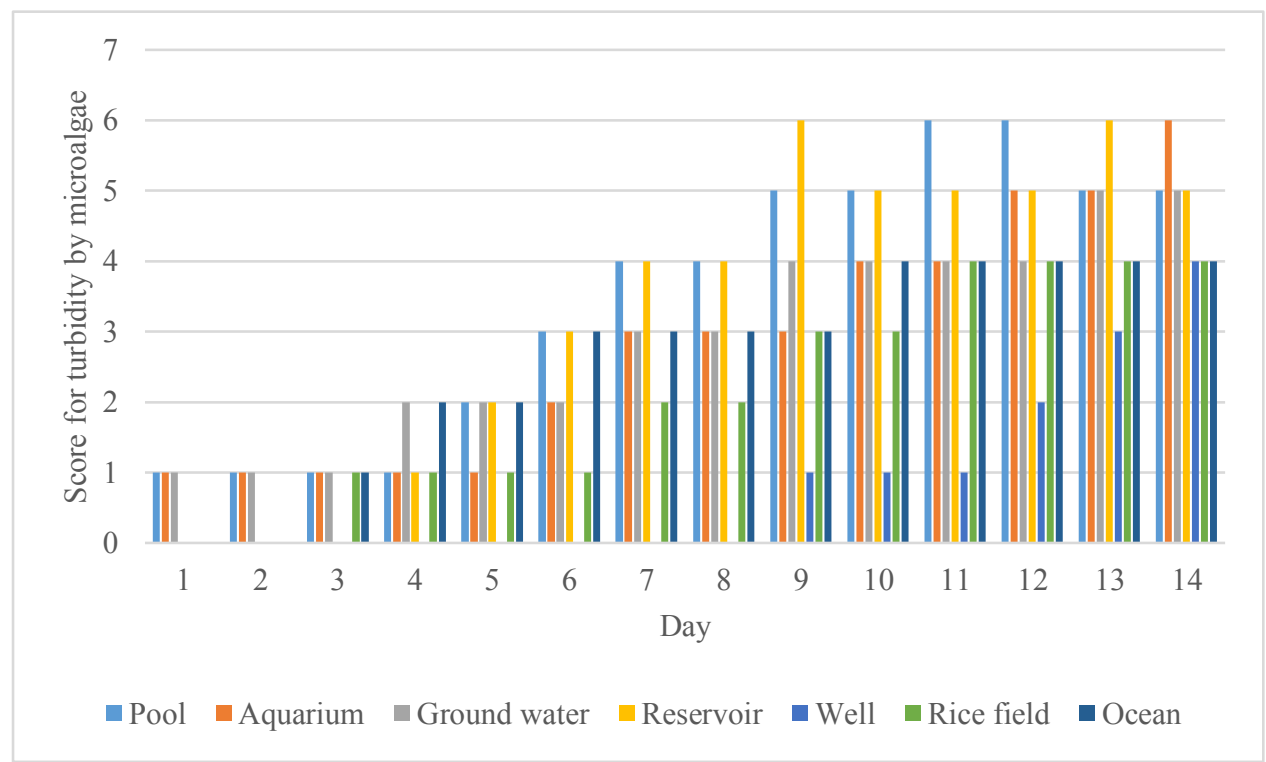

Fig. 5. Microalgae population growth

Based on observations for 14 days, The rainwater was clear on the first day. On the 12th day, the rainwater showed a colour change that looked like a change in colour to cloudy (Fig 5), and there was the appearance of a microbial-like shape. There are green dots at the bottom of the water, but the water is still clear. On the 14th day, the rainwater looks green. It was suspected that there is green algae growth in rainwater.

Whereas the culture bottle filled with water from the aquarium becomes muddy colour changes to yellow on day 6 (Fig 5). This indicated that in the aquarium water, some microalgae breed. On the seventh day a dark green precipitate began to form at the bottom of the aquarium bottle. The increase in sediment in each bottle was caused by the growth of 
microalgae colonies. At the beginning of culture, the nutrient content in the media was still high so that it could be utilized by phytoplankton to carry out the growth process.

There was also a change in the water's colour coming from the pool. On the 5 th day of observation, the colour of the water turns feculent and brown, as if there was a brown floating object, there was sediment on the bottom surface of the bottle. The colour of the pool was clearer on the 9th day rather than on the 11th day. On the 14th day of observation, the colour of the pool water appeared to be brown and cloudy again. It was seen that the colour of the pool water was not as brown and dark as the previous days, this indicated a stationary phase and the nutrient content is getting thinner and the micro-algae population or cell number is decreasing due to the limited nutrient content in the culture media.

The rice field water sample was initially clear, then on the 3rd day there were dots on the bottom of the water, and the water looked yellowish. Observations on rice field water samples showed a slight change in green colour on day 9 and a slight green precipitate starting on day 11. The colour of the water became overcast with light green on day 11 and was stagnant until the last day of observation. On the first day, the groundwater sample was quite thick green because it had come from the source when it was taken, on the 7th day it was found that the green groundwater was quite thick and formed a little sediment and increased on day 9. The peak of growth was on the last day of observation.

Observations on well water sample showed that on the first day of observation until day 8 was clear, then it looked a little cloudy and showed a little sediment on day 9 and still showed no colour change until day 11 . The environment where the water was taken is still relatively good because the well where the water taken was surrounded by shrubs and trees. The cloudy well water on the first day of observation was possible because the water was taken after it rained. But it increased rapidly on the last 3 days of observation.

Reservoir water sample was taken from the Diponegoro Educational Reservoir experienced a colour change which indicated the presence of micro-algae. Initially the water was clear, until day 4 it formed green colour. The peak of micro-algae growth was in day 9 and 13.

The seawater sample initially showed a clear colour, on the 3rd day it was yellow and a precipitate appeared on the 4th to 14th day, then a salt deposit appeared at the bottom of the container and it looked yellow-green. The micor-algae growth increased in a slow pace until the last day of observation.

\section{Discussion}

PDAM water and mineral water are not overgrown with microalgae which might be due to the lack of nutrients in the water and the condition of the water that has undergone further processing such as purification using chemicals or distillation so that it is suitable for consumption. It is carried out in several stages, namely: the water filtering process, the sludge and dirt deposition process, the clarification process (coagulation, flocculation, and sedimentation), the filtering process (sand filter), the disinfection process (addition of lime and chlorine) [7]. Hence the microalgae are not present. Whereas the river water can be assumed to contain sufficient nutrients for microalgae growth because it is located in the middle of the city which allows many agricultural by-products such as fertilizers to be dissolved in river water [8]. The abundance of phytoplankton in the river might be dominated by the Synedra sp. These Bacillariophyceae can be found in almost every aquatic environment with sufficient sunlight to maintain activity. Synedra sp. has a high abundance and can be found in various habitats such as wet soil, rock walls, steep coral, peat, and bark. Some diatoms live as epiphytes on other algae or wild plants [9]. Ulothrix sp. could also be dominating the water, which is a species of green algae in the form of filaments. The body of Ulothrix sp. consists of cells that are cylindrical in shape and arranged lengthwise like 
threads. This algae lives in fresh water where the water is not too warm and lives attached to rocks or at the bottom of the water [10]. On the other hand, spring water also has sufficient nutrients for microalgae growth, although not as much as river water. In addition, Green coloured water deposits indicate that there are microalgae from the green algae (Chlorophyta) group and brown coloured water indicates the presence of microalgae from the diatom, crysophyta group [11]. Diatom pigments have more yellow colour than green pigments make, which also known as golden brown algae [12]. Microalgae are divided into two categories, namely pelagic and benthic microalgae $[13,14]$. Pelagic microalgae are microalgae suspended in water bodies. In contrast to benthic microalgae, they grow on the surface of bottom sediments and are often filamentous, but some are microscopic single cells. River water allows for dissolved nutrients such as nitrogen. The slow and slightly calmer river flow is an additional point for the growth of microalgae [14, 15].

The puddle water used comes from a barrel which is shallow enough so that light intensity can enter and can help microalgae to photosynthesize. Puddle water at least has nutrients that are able to support microalgae life even though it is not as high as river and spring water. This may be due to the nutrients in puddle water were easily washed away when exposed to rain so it would be replaced by new water and requires time for microalgae to adapt and grow. Rain could disrupt an important mechanism that regulates algae growth. The rain itself will dilute or overflow the water, which may reduce the concentration of algae and nutrients in the water [16].

Brown deposits appeared in the wastewater which indicated micro-algae growth. Wastewater contains organic carbon and other compounds, such as high nitrogen and phosphorous, that can be used for the cultivation of microalgae. The population growth of micro-algae in the textile wastewater depends also on critical variables such as $\mathrm{pH}$, temperature, availability of light, $\mathrm{CO} 2$ and $\mathrm{O} 2$ [17].

Samples of rainwater showed a colour change in the observations of the last two days in the form of a green colour appearing at the bottom of the bottle. The micro-algae that grew in the rainwater samples that were stagnant in the bottles were thought to come from the Chlorophyta group because the micro-algae from that group had chlorophyll pigments so that the colony formed a green colour. Green algae or Chlorophyta are algae that contain more dominant chlorophyll [18].

Yellow aquarium water is caused by the presence of ammonia compounds from fish feces, where the longer you leave it, the clearer the water will be due to the evaporation process. Ammonia in aquarium water can be lost through the process of volatilization (evaporation) because the partial pressure of ammonia in solution increases with increasing $\mathrm{pH}[19]$.

The pool water turned cloudy and there was sediment at the bottom of the bottle, possibly caused by micro-algae in the pool water. In pool water, there is a colour change and there is sediment or dirt from the pool water that settles, there may be a lot of micro-algae in the pool water, there are yellow, brown, and green spots in the bottle, the possibility of microorganisms living in pool water. Pool water has a $\mathrm{pH}$ of less than 7 or acidic water where the Chlorophyceae class micro-algae can grow well, such as the example of Chlorella sp. [20]. The peak growh of microalgae was on the 12th and 13th day and it decreases on the last day of the observation by the colour change of water. This means that the phase of microalgae growth has changed and the microalgae presence reduced. Chlorella vulgaris not only reduces the pollutant load $\left(\mathrm{COD}, \mathrm{NH}_{4}-\mathrm{N}\right.$, and $\left.\mathrm{PO}_{4}-\mathrm{P}\right)$ but also the colour during remediation of textile wastewater [15].

The sample of rice field water on the fourth day is the same as in the aquarium, which changes from sediment to yellow-green under the sediment, this shows that in the water there is also micro-algae growing. Nutrients in stagnant water are also in accordance with the surrounding soil conditions. Large puddles are likely to be overgrown with microorganisms 
or micro-algae and waters with calmer and less heavy currents like rice fields will allow the presence of micro-algae. The low current velocity in water causes a high abundance in the class Chlorophyceae, namely green algae [10,21].

Ground water showed a slow pace growth increased until the last day of observation. The abundance of microalgae in the groundwater might be dominated by Chlamydomonas. Microalgae that have the ability in decomposing insecticidal compounds, one must has a high tolerance so that able to live, grow and develop well in a polluted environment insecticide. Chlamydomonas is known as one of the tolerant microalgae genera against pollution. The growth rate of Chlamydomonas culture on days 1-7 on groundwater medium was higher than that of Beneck medium [22]. This indicates that there are microalgae growing in the soil.

There was no significant change in well water from day 1 to day 8 , probably due to good water quality. The quality of well water can be affected by sewage or household wastewater, chemical waste, laundry, seepage of polluted nearby river water, and others. Good quality can be seen from the smell and colour of the water from the source, clear and odorless colours indicate very good water quality. The colour change to greenish turbid and green sediment is found in the well water, it is suspected that the water contains the photosynthetic micro-algae Chlorophyceae which has green chlorophyll [23]. The cloudy well water observation was possible because the water was taken after it rained. The physical quality of well water is usually influenced by seasonal conditions so that if sampling is carried out in the rainy season, it is likely that the physical quality will decrease, such as increasing the level of turbidity, due to a large number of suspended solutions in the water [24]. The well water was cloudier on the last day of observation than on the first day, showed little sediment, and remained colourless. Green algae (Chlorophyceae) have green pigments. While the brown colour in the pool water sample is thought to contain brown algae Phaeophyceae which have xanthophyll pigments [25].

Water taken from the reservoir showed the highest growth on the 9th and 13th which would indicated the peak growth of micro-algae. After an increase in the number of cells to a point in the population peak, cell growth will stop [15]. The growth phase of microalgae consists of lag, exponential, stationary, and death phases. The lag phase does not see any changes. The exponential phase is indicated by a change in the colour of the water to green and cloudy. The stationary phase is shown in green in fixed water. The death phase is shown in green when the water starts to fade or the water looks clearer [26]. Reservoir water contains organic material that can be used by micro-algae. Lake or reservoir waters are generally dominated by phytoplankton, from the class of Chlorophyceae, Bacillariophyceae, and Cyanophyceae. Chlorophyta are green algae which, if they are numerous and dominate the waters, will make the waters look greenish, while Bacillariophyceae is phytoplankton, known as diatoms [27].

In seawater, the yellow-green colour is assumed that there is an indication of micro-algae growth by yellow-green algae (xanthophytes), which has chlorophyll E pigment [28]. Compared with freshwater, seawater contains more dissolved ions, the most abundant are sodium, chloride, magnesium, sulfate, and calcium, which are required for micro-algae to growth, including various minerals, such as nitrogen sources and phosphate sources [29].

The growth of micro-algae colonies in each bottle was caused by the fulfillment of nutrients, temperature, oxygen levels, humidity, light. The formation of green colour in the form of a precipitate is caused by the presence of micro-algae Chlorophyta because it has a green pigment (chlorophyll) [11,30-32]. The growth of micro-algae can be influenced by environmental factors, including humidity, temperature, salinity, and light. Cultivation and harvesting of micro-algae is carried out until the age of micro-algae reaches the final stationary phase, related to the growth phase of micro-algae [33]. 


\title{
Conclusion
}

The changes of colour indicated the growth of microalgae in the bottle. Brown coloured water indicated diatom, Crysophyta group, whereas green coloured water indicated green algae or Chlorophyta group. This simple experiment was able to be developed for practical work during pandemic Covid-19, when students have to study at home, but are still able to get their competence by small project-based learning.

\begin{abstract}
Akcnowledgment
Thanks to assistants of Protist Practical Work especially to Odah, Hanna, Lidia, Oki, Safira, Christopher, Nursriana, Della, Iren and Kay who had supported during the lab practice and the students of Department Biology Universitas Diponegoro 2019 for their help in collecting the data.
\end{abstract}

\section{References}

1. M. I. Khan, J. H. Shin, and J. D. Kim. The promising future of microalgae: current status, challenges, and optimization of a sustainable and renewable industry for biofuels, feed, and other products. Microb. Cell Fact. 17, 36, 1-21 (2018). https://doi.org/10.1186/s12934-018-0879-x

2. D. Singer, C. V. Seppey, G. Lentendu, M. Dunthorn, D. Bass, L. Belbahri, Q. Blandenier, D. Debroas, G. A. de Groot, C. de Vargas, I. Domaizon, C. Duckert, I. Izaguirre, I. Koenig, G. Mataloni, M. R. Schiaffino, E. A. D. Mitchell, S. Geisen, and E. Lara. Protist taxonomic and functional diversity in soil, freshwater and marine ecosystems. Env. Int. 146, 106262, 1-8 (2021). https://doi.org/10.1016/j.envint.2020.106262

3. R. R. Narala, S. Garg, K. Sharma, S. R. Thomas, M. Deme, Y. Li, and P. M. Schenk. Comparison of Microalgae Cultivation in Photobioreactor, Open Raceway Pond, and a Two-Stage Hybrid System. Front. Energy Res. 4, 29, 1-10 (2016). https://doi.org/10.3389/fenrg.2016.00029

4. Q. Huang, J. Fuhua, W. Lianzhou and C. Yang. Design of Photobioreactors for Mass Cultivation of Photosynthetic Organisms. Eng. 3, 3, 318-329 (2017). https://doi.org/10.1016/J.ENG.2017.03.020

5. S. Hemaiswarya, R. Raja, R. Kumar, V. Ganesan and C. Anbazhagan. Microalgae: A sustainable feed source for aquaculture. Wrld. J. Microbiol. Biotechnol. 27, 1737-1746. (2011). 10.1007/s11274-010-0632-Z

6. D. T. Zewdie and A. Y. Ali. Cultivation of microalgae for biofuel production: coupling with sugarcane-processing factories. Energ. Sustai.n Soc. 10, 27, 1-16 (2020). https://doi.org/10.1186/s13705-020-00262-5

7. M. Kencanawati. Analisis Pengolahan Air Bersih Pada WTP PDAM Prapatan Kota Balikpapan. J. Ilm. T. S. Trnskm. 2, 103-117 (2017). https://transukma.unibabpn.ac.id/index.php/transukma/article/view/51

8. U. Kalana, C. Kalpage and S. Yatigammana. Evaluation of the suitable environmental conditions for selected freshwater microalgae species with the potential for the production of biodiesel. Ceylon J. Sci. 45, 3, 93-101 (2016). 10.4038/cjs.v45i3.7405

9. D. Isti'anah, M. F. Huda and A. N. Laily. Synedra sp. sebagai Mikroalga yang Ditemukan di Sungai Besuki Porong Sidoarjo, Jawa Timur. Bioedukasi. 8,1, 57-59 (2015). https://jurnal.uns.ac.id/bioedukasi/article/view/3500/2978 
10. S. M. Fauziah and L. Ainun. Identifikasi Mikroalga dari Divisi Chlorophyta di Waduk Sumber Air Jaya Dusun Krebet Kecamatan Bululawang Kabupaten Malang. J. Uns. 8, 1, 20-22 (2015). 10.20961/bioedukasi-uns.v8i1.3150

11. J. Mateo-Sagasta, S. M. Zadeh, H. Turral and J. Burk. Water pollution from agriculture: a global review. Executive summary. Rome, Italy: FAO; Colombo, Sri Lanka: International Water Management Institute (IWMI). CGIAR Research Program on Water, Land and Ecosystems (WLE). 35p (2017). https://hdl.handle.net/10568/88070

12. S. Kumar, P. Baweja and D. Sahoo. Diatoms: Yellow or Golden Brown Algae. In: Sahoo D., Seckbach J. The Algae World. Cellular Origin, Life in Extreme Habitats and Astrobiology. 26 (Springer, Dordrecht 2015).

13. A. Abonyi, M. Leitão, I. Stanković, G. Borics, G. Várbíró and J. Padisák. A large river survey to compare phytoplankton functional approaches: do they display river zones in similar ways? Ecol. Indctrs. 46, 11-22 (2014).

https://doi.org/10.1016/j.ecolind.2014.05.038

14. N. Wu, X. Dong, Y. Liu, C. Wang, A. Baattrup-Pedersen and T. Riis. Using river microalgae as indicators for freshwater biomonitoring: Review of published research and future directions. Eco. Indi. 81, 124-131 (2017). 10.1016/j.ecolind.2017.05.066

15. K. W. Chew, S. R. Chia, P. L. Show, Y. J. Yap, T. C. Ling and J. Chang. Effects of water culture medium, cultivation systems and growth modes for Microalgae Cultivation: A review in J. Taiwan Ins. Chm. Eng. 91, 332-344 (2018). https://doi.org/10.1016/j.jtice.2018.05.039

16. A. P. F. Pires, J. D. S. Leal and E. T. H. M. Peeters. Rainfall changes affect the algae dominance in tank bromeliad ecosystems. PLOS ONE. 12, 4, 1-15 (2017).https://doi.org/10.1371/journal.pone.0175436 A., Leal, J. Peete

17. T. R. Soeprobowati and R. Hariyati. The phycoremediation of textile wastewater discharge by Chlorella pyrenoidosa H. Chick, Arthrospira platensis Gomont, and Chaetoceros calcitrans (Paulson) H. Takano. AACL Bioflux 10, 3, 640-651 (2017). http://www.bioflux.com.ro/home/volume-10-3-2017/

18. L. Pereira. Macroalgae. Encyclopedia. 1, 177-188 (2021). https://doi.org/10.3390/encyclopedia1010017

19. Z. Ma, Y. Yue, M. Feng, Y. Li, X. Ma, X. Zhao and S. Wang. Mitigation of ammonia volatilization and nitrate leaching via loss control urea triggered H-bond forces. Sci Rep. 9, 15140, 1-9 (2019). https://doi.org/10.1038/s41598-019-51566-2

20. D. Jumiarni. Kultur Mikroalga dari Rawa Gambut: Studi Pendahuluan Potensi Mikroalga Sebagai Bahan Baku Biodiesel. Biodidaktika. 13, 1, 47-56 (2018). p-ISSN: 1907-087X; e-ISSN: 2527-4562

21. Harmoko, M. Triyanti and L. Aziz. Eksplorasi Mikroalga Di Sungai Mesat Kota Lubuklinggau. Biodidaktika. 13, 19-23 (2018). 1907-087X; e-ISSN: 2527-4562

22. M. Kurniasih, N. B. Prihantini and E. Nurtiyani. Pertumbuhan Mikroalga Chlamydomonas dalam Medium Beneck dan Air Tanah yang Mengandung Insektisida $\begin{array}{llllll}\text { Berbahan } & \text { Aktif } & \text { Klorpirifos. } & \text { Biota. } & \mathbf{8}, & 1,\end{array}$ (2019). https://doi.org/10.24002/biota.v8i1.2827

23. Sasongko, B. Endar, E. Widyastutu and R. Priyono. Kajian Kualitas Air dan Penggunaan Sumur Gali Oleh Masyarakat di Sekitar Sungai Kaliyasa Kabupaten Cilacap. J. Il. Lingk. Undip. 12, 2, 72-82 (2014). https://doi.org/10.14710/jil.12.2.72-82 
24. S. Puspita and J. Mukono. Hubungan Kualitas Bakteriologis Air Sumur dan Perilaku Sehat dengan Kejadian Waterborne Disease di Desa Tambak Sumur, Kecamatan Waru, Kabupaten Sidoarjo. J. Kes. Ling. 7, 1, 76-82 (2013).

25. A. G. Pereira, P. Otero, J. Echave, A. Carreira-Casais, F. Chamorro, N. Collazo,a. Jaboui, C. Lourenço-Lopes, J. Simal-Gandara, and M. A. Prieto. Xanthophylls from the Sea: Algae as Source of Bioactive Carotenoids. Mar. Drugs. 19, 188, 1-31 (2021). https://doi.org/10.3390/md19040188

26. N. Serri, L. Anbalagan, N. Norafand, M. Kassim, M. S. Mansor. Preliminary study on the growth of Tetraselmis suecica in centred-light photobioreactor (CLPBR). IOP Conference Series: Materials Science and Engineering. 716, 1-8 (2020). 012008. 10.1088/1757-899X/716/1/012008.

27. S. R. Samudra, T. R. Soeprobowati, and M. Izzati. Komposisi, Kemelimpahan dan Keanekaragaman Fitoplankton Danau Rawa Pening Kabupaten Semarang. Bioma. 15, 1, 6-13 (2013). 10.14710/bioma.15.1.6-13.

28. C. Osório, S. Machado, J. Peixoto, S. Bessada, F. B. Pimentel, R. Alves, and O. Beatriz. Pigments Content (Chlorophylls, Fucoxanthin and Phycobiliproteins) of Different Commercial Dried Algae. Separations. 7, 2, 1-14 (2020). https://doi.org/10.3390/separations7020033

29. J. Y. Jung, H. Lee, W. Shin, M. Sung, J. Kwon, and J. Yang. Utilization of seawater for cost-effective cultivation and harvesting of Scenedesmus obliquus. Bioprocess biosyts. eng. 38, 3, 449-455 (2014). 10.1007/s00449-014-1284-4.

30. R. Kristian, S. Raharjo, and S. Sulastrianah. Uji Aktivitas Antioksidan Mikroalga Air Tawar. Medula. 3, 1, 201-207 (2015). http://dx.doi.org/10.46496/medula.v3i1.2537

31. D. Amalo, G. L. Manggadas, and D. B. Herlinda. Pengaruh Konsentrasi Air Kelapa Terhadap Pertumbuhan Mikroalga Chlorella vulgaris. J. Biotrop. Sain. 16, 1, $28-39$ (2019)

32. D. J. Arianto, H. P. Paramastri, and D. Soetrisnanto. Potensi Air Dadih (Whey) Tahu sebagai Nutrien dalam Kultivasi Chlorella sp. untuk Bahan Baku Pembuatan Biodisel. J. Tek. Kim. Ind. 2, 4, 233-242. (2013). http://ejournal-s1.undip.ac.id/index.php/jtki

33. T. R. Soeprobowati and R. Hariyati. Bioaccumulation of $\mathrm{Pb}, \mathrm{Cd}, \mathrm{Cu}$, and $\mathrm{Cr}$ by Porphyridium cruentum (S.F. Gray) Nägeli. Int. J. Mar. Sci. 3, 27, 212-218 (2013). doi: 10.5376/ijms.2013.03.0027http://www.aquapublisher.com/index.php/ijms/article/view/ $\underline{797}$ 